\title{
Next generation sequencing-based salivary biomarkers in oral squamous cell carcinoma
}

\author{
Buyanbileg Sodnom-Ish, Mi Young Eo, Hoon Myoung, Jong Ho Lee, Soung Min Kim \\ Department of Oral and Maxillofacial Surgery, School of Dentistry, Dental Research Institute, Seoul National University, Seoul, Korea
}

\begin{abstract}
J Korean Assoc Oral Maxillofac Surg 2022;48:3-12)
Selection of potential disease-specific biomarkers from saliva or epithelial tissues through next generation sequencing (NGS)-based protein studies has recently become possible. The early diagnosis of oral squamous cell carcinoma (OSCC) has been difficult, if not impossible, until now due to the lack of an effective OSCC biomarker and efficient molecular validation method. The aim of this study was to summarize the advances in the application of NGS in cancer research and to propose potential proteomic and genomic saliva biomarkers for NGS-based study in OSCC screening and diagnosis programs. We have reviewed four categories including definitions and use of NGS, salivary biomarkers and OSCC, current biomarkers using the NGSbased technique, and potential salivary biomarker candidates in OSCC using NGS.
\end{abstract}

Key words: Next generation sequencing, Saliva, Biomarkers, Early diagnosis, Oral squamous cell carcinoma

[paper submitted 2021. 12. 6 / accepted 2022. 1. 11]

\section{Introduction}

Oral squamous cell carcinoma (OSCC) accounts for 90\%$96 \%$ incidence of whole head and neck cancers, but there are no sensitive biomarkers for detection of OSCC. Definitive diagnosis has only been possible after examination of removed specimens. This diagnosis has been based on pathological findings such as angiogenesis, proliferation, and metastasis.

Even with radical resection combined with chemotherapy and concurrent radiation therapy, many OSCC cases demonstrate metastasis or recurrence without related or predictive symptoms. Complete eradication, early diagnosis, and metastatic and prognostic factor discovery have been research aims for OSCC management; until now, however, fulfillment of these aims has been elusive.

Like many cancers, early-stage OSCC is difficult to detect.

\author{
Soung Min Kim \\ Department of Oral and Maxillofacial Surgery, School of Dentistry, Dental \\ Research Institute, Seoul National University, 101 Daehak-ro, Jongno-gu, \\ Seoul 03080, Korea \\ TEL: +82-2-2072-0213 \\ E-mail:smin5@snu.ac.kr \\ ORCID: https://orcid.org/0000-0002-6916-0489
}

(c) This is an open-access article distributed under the terms of the Creative Commons Attribution Non-Commercial License (http://creativecommons.org/ licenses/by-nc/4.0/), which permits unrestricted non-commercial use, distribution, and reproduction in any medium, provided the original work is properly cited.

Copyright (C) 2022 The Korean Association of Oral and Maxillofacial Surgeons.
A significant number of patients do not seek clinical care until the OSCC is in an advanced stage. The development and advancement of screening and early diagnosis approaches has been recommended as the most effective strategy for reducing the OSCC-related morbidity and mortality rate ${ }^{1}$. Biomarkers found in the saliva are an ideal non-invasive diagnostic tool for early diagnosis of cancer ${ }^{2-4}$. Compared to blood and tissue sampling, saliva sampling is a reliable, noninvasive, convenient, and economical alternative for disease diagnosis and prognosis determination ${ }^{5}$. Saliva sampling also provides an effective and easily-acquired liquid specimen for large-scale sampling, epidemiologic screening and long-term monitoring ${ }^{6}$.

Several DNA or RNA sequencing techniques using salivary specimens have been used for karyotyping or submicroscopic chromosomal copy number changes such as microdeletions. These techniques include immunoprecipitation high-performance liquid chromatography, radioimmunoassay, electrophoretic immunoassay, mass spectrometry-based proteomics, microchips or microarrays, microfluidic devices, electrochemical biosensors ${ }^{7,8}$, fluorescence in situ hybridization and comparative genomic hybridization microarrays. Maxam and Gilbert ${ }^{9}$ DNA sequencing was first developed in 1976 and is based on nucleobase-specific partial chemical modification of DNA and subsequent cleavage of the DNA backbone at sites 
adjacent to the modified nucleotides. This sequencing method was advanced by Sanger et al. ${ }^{10}$ in 1977. Sanger sequencing ${ }^{10}$, also known as chain termination sequencing, was marketed commercially by Applied Biosystems in $1986^{11}$ and was the most popular DNA sequencing method until now. These two methods are based on the dideoxy method, the selective incorporation of chain-terminating dideoxynucleotides by DNA polymerase during in vitro DNA replication ${ }^{10,12}$. These first generation sequencing methods have been improved upon in next-generation sequencing (NGS).(Fig. 1)

NGS is a massive and parallel DNA sequencing technology for large-scale, ultra-high throughput, and automated highspeed genome analyses. NGS is a less expensive method for determining the order of nucleotides in entire genomes or targeted regions of DNA or RNA and has revolutionized the biological sciences. NGS has a wide variety of applications for the study of biological systems at a new level. NGS can be used to sequence entire genomes or specific areas of interest $^{13}$. Sanger sequencing continues to be useful for smallerscale, short-read sequencing analysis and for the validation of NGS results ${ }^{14}$.

The effectiveness of NGS in whole exome sequencing by targeted sequencing of cancer-related genes and in RNA sequencing has been demonstrated. NGS-applied OSCC research has also identified various genetic alterations and detected mutations with low variant allele frequency ${ }^{15}$. NGS is also becoming an essential method in characterization of salivary gland tumors ${ }^{16}$. However, NGS has only rarely been applied to the identification of salivary biomarkers of OSCC. We discuss four topics in this review article: definitions and use of NGS, salivary biomarkers and OSCC, current biomarkers using NGS-based technique, and potential candidates as NGS-based salivary biomarkers.

\section{Definitions and Use of NGS}

In the field of functional genomics, NGS is the most useful method for DNA and RNA analysis. This highly reproducible tool can reveal single nucleotide polymorphisms, related gene variants or spliced transcripts without input of direct DNA or RNA features as in microarray procedures. NGS can also be applied to cDNA molecules for RNA sequencing by reverse transcription from candidate RNA and sequencinglibrary construction by massive parallel deep sequencing. The most popular NGS methods are summarized in Table $1^{17-31}$. Illumina Solexa sequencing uses a fluorescence-based Illumina platform to identify $100-150$ bp of DNA by emitting a particular fluorescent signal to each chain of nucleic acid. Adaptors can fragment, ligate and anneal longer sequences randomly. Reading is carried out by polymerase chain reaction (PCR) amplification and creation of a unique spot that repeats. The product can be separated into a single strand for final sequencing.(Fig. 1)

The sequencing-by-sequence methods using pyrosequenc-
Sanger sequencing

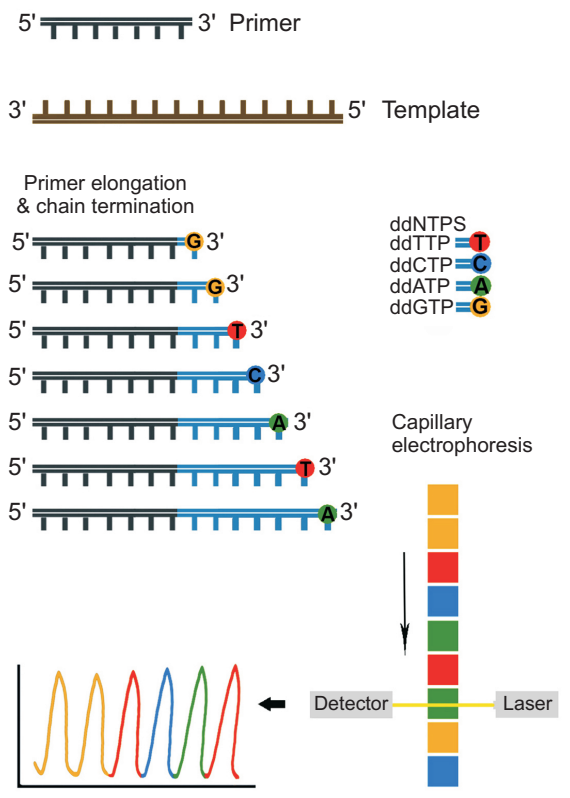

Next generation sequencing (NGS)

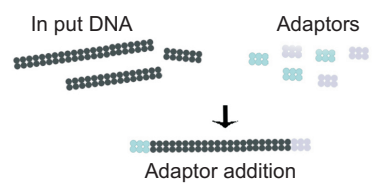

Sequencing method 1: bridge PCR
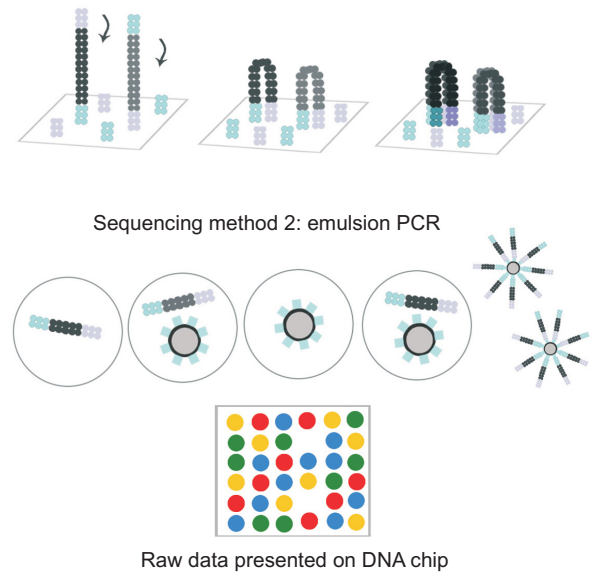

Fig. 1. Schematic drawing of the Maxam and Gilbert's chemical chain termination method for DNA sequencing developed in 1977 followed by Sanger's 'dideoxy method', ${ }^{10}$. (PCR: polymerase chain reaction)

Buyanbileg Sodnom-Ish et al: Next generation sequencing-based salivary biomarkers in oral squamous cell carcinoma. J Korean Assoc Oral Maxillofac Surg 2022 
Table 1. Next generation sequencing platforms ${ }^{17}$

\begin{tabular}{|c|c|c|c|c|c|c|}
\hline Platform & $\begin{array}{l}\text { Template } \\
\text { preparation }\end{array}$ & $\begin{array}{l}\text { Detection } \\
\text { method }\end{array}$ & $\begin{array}{l}\text { NGS } \\
\text { coverage } \\
\text { (base) }\end{array}$ & $\begin{array}{l}\text { Run time } \\
\text { (day) }\end{array}$ & $\begin{array}{l}\text { Gb per } \\
\text { run }\end{array}$ & Essential descriptions \\
\hline $\begin{array}{l}\text { Roche } 454 \\
\text { (Roche, Basel, } \\
\text { Switzerland) }{ }^{18}\end{array}$ & $\begin{array}{l}\text { Emulsion- } \\
\text { based clonal } \\
\text { amplification }\end{array}$ & Pyrosequencing & $400 *$ & 0.42 & $0.40-0.60$ & $\begin{array}{l}\text { First commercial platform for the NGS tech- } \\
\text { nology. The DNA amplification process is } \\
\text { different from that of Illumina, which can } \\
\text { sequence much longer reads }{ }^{19} \text {. }\end{array}$ \\
\hline $\begin{array}{l}\text { GS FLX Titanium } \\
(\text { Roche })^{20}\end{array}$ & & & $400 *$ & 0.42 & 0.035 & $\begin{array}{l}\text { Able to sequence } 400-600 \text { million base pairs } \\
\text { per run with } 400-500 \text { base pair read lengths }{ }^{21} \text {. }\end{array}$ \\
\hline $\begin{array}{l}\text { Illumina MiSeq } \\
\text { (Illumina, San } \\
\text { Diego, CA, USA) }{ }^{22}\end{array}$ & $\begin{array}{l}\text { Clonal bridge } \\
\text { PCR }\end{array}$ & $\begin{array}{l}\text { Reversible dye } \\
\text { terminator }\end{array}$ & $2 \times 300$ & $\begin{array}{c}0.17- \\
2.7\end{array}$ & 15 & $\begin{array}{l}\text { End-to-end sequencing solutions with reversible- } \\
\text { terminator sequencing-by-synthesis. } \\
\text { Smallest benchtop sequencer that can perform } \\
\text { onboard cluster generation, amplification, } \\
\text { genomic DNA sequencing, and data analysis } \\
\text { in a single run. Performs both single- and } \\
\text { paired-end runs with adjustable read lengths } \\
\text { from } 1 \times 36 \text { base pairs to } 2 \times 300 \text { base pairs }{ }^{22} \text {. }\end{array}$ \\
\hline $\begin{array}{l}\text { Illumina HiSeq } \\
{\text { (Illumina })^{23}}^{23}\end{array}$ & & & $2 \times 150$ & $0.3-11$ & 1,000 & $\begin{array}{l}\text { Generate up to } 1,000 \mathrm{~Gb} \text { per run with the highest } \\
\text { yield of data greater than Phred quality score } \\
\text { of } 30(\mathrm{Q} 30) \text {. } \\
1 \text { hour's cycle time can be reduced to } 10 \text { minutes } \\
23\end{array}$ \\
\hline $\begin{array}{l}\text { Illumina Genome } \\
\text { Analyzer IIX } \\
\text { (Illumina) }^{24}\end{array}$ & & & $2 \times 150$ & $2-14$ & 95 & $\begin{array}{l}\text { Having a broad spectrum of genomic variation } \\
\text { with short- and long-insert paired-end reads } \\
\text { with insert sizes } 200 \mathrm{bp} \text { to } 5 \mathrm{~kb} \text {. } \\
\text { Used for studying the genome, epigenome, and } \\
\text { transcriptome, and also yield greater than } 85 \% \\
\text { of bases higher than Q30 at } 2 \times 50 \mathrm{bp}^{24} \text {. }\end{array}$ \\
\hline $\begin{array}{l}\text { Life Technologies } \\
\text { SOLiD4 (Life } \\
\text { Technologies, } \\
\text { Waltham, MA, } \\
\text { USA) }\end{array}$ & $\begin{array}{l}\text { Emulsion- } \\
\text { based clonal } \\
\text { amplification }\end{array}$ & $\begin{array}{l}\text { Oligonucleotide } \\
\text { ligation } \\
\text { detection }\end{array}$ & $35-50$ & $4-7$ & $35-50$ & $\begin{array}{l}\text { Generates } 10^{8}-10^{9} \text { small sequence reads at one } \\
\text { time, and two-base base encoding to decode the } \\
\text { raw data. This system utilizes four fluorescent } \\
\text { dyes to interrogate all sixteen }\left(4^{2}\right) \text { possible two- } \\
\text { base combinations, by a number of probes. } \\
\text { Each probe is eight nucleotides long }(8-\text { mer })^{26} \text {. }\end{array}$ \\
\hline $\begin{array}{l}\text { Life Technologies } \\
\text { Ion Protons } \\
\text { (Thermo Fisher } \\
\text { Scientific, Waltham, } \\
\text { MA, USA) }{ }^{27}\end{array}$ & & $\begin{array}{l}\text { Native deoxy- } \\
\text { ribonucleotide } \\
\text { triphosphates, } \\
\text { proton } \\
\text { detection }\end{array}$ & 200 & 0.5 & 100 & $\begin{array}{l}\text { Does not use fluorescence or chemiluminescence. } \\
\text { Instead, measures the } \mathrm{H}+\text { ions released during } \\
\text { base incorporation. The lack of any optics } \\
\text { allows rapid expansion of the output by } \\
\text { approximately 10-fold every six months }{ }^{27} \text {. }\end{array}$ \\
\hline $\begin{array}{l}\text { Complete Genomics } \\
\text { (Complete } \\
\text { Genomics, San } \\
\text { Jose, CA, USA) }{ }^{28}\end{array}$ & $\begin{array}{l}\text { Gridded DNA- } \\
\text { nanoballs }\end{array}$ & $\begin{array}{l}\text { Oligonucleotide } \\
\text { ligation } \\
\text { detection }\end{array}$ & $7 \times 10$ & 11 & 3,000 & $\begin{array}{l}\text { A DNA nanoball sequencing, which assembles } \\
\text { short DNA sequences into a full genome. } \\
\text { The sequences are obtained by probe-ligation, } \\
\text { but the clonal DNA amplification is performed } \\
\text { by rolling circle amplification unlike the bead } \\
\text { or emulsion amplification }{ }^{28} \text {. }\end{array}$ \\
\hline $\begin{array}{l}\text { Helicos Biosciences } \\
\text { Heliscope (Helicos } \\
\text { Biosciences, } \\
\text { Cambridge, MA, } \\
\text { USA) }\end{array}$ & $\begin{array}{l}\text { Single } \\
\text { molecule }\end{array}$ & $\begin{array}{l}\text { Reversible dye } \\
\text { terminator }\end{array}$ & $35^{*}$ & 8 & 25 & $\begin{array}{l}\text { A highly sensitive fluorescence detection system } \\
\text { for direct interrogation of single DNA } \\
\text { molecules via sequencing by synthesis }{ }^{30} \text {. }\end{array}$ \\
\hline $\begin{array}{l}\text { Pacific Biosciences } \\
\text { SMRT (Pacific } \\
\text { Biosciences, Menlo } \\
\text { Park, CA, USA) }{ }^{31}\end{array}$ & & $\begin{array}{l}\text { Phospholinked } \\
\text { fluorescent } \\
\text { nucleotides } \\
\text { or real-time } \\
\text { sequencing }\end{array}$ & $\begin{array}{l}10,000 \\
(\mathrm{~N} 50) \\
30,000+ \\
(\max )\end{array}$ & 0.08 & 0.5 & $\begin{array}{l}\text { Long-read sequencing platforms with SMRT } \\
\text { sequencing technology. Template preparation } \\
\text { does not require any amplification steps, and the } \\
\text { prepared library molecule is the sequencing } \\
\text { template. } \\
\text { The adapters have a hairpin structure (SMRT } \\
\text { loop adapters) so that after ligation the double } \\
\text { stranded DNA fragments will have become } \\
\text { circular }^{31} \text {. }\end{array}$ \\
\hline
\end{tabular}

(PCR: polymerase chain reaction, NGS: next generation sequencing, SMRT: single molecule real-time)

*Average read lengths for the Roche 454 and Helicos Biosciences platforms.

Q30 is equivalent to the probability of incorrect base call 1 in 1,000 times with $99.9 \%$ base of accuracy. Run times and gigabase (Gb) output per run for single-end sequencing are noted. Run times and outputs approximately double when performing pair-end sequencing.

Buyanbileg Sodnom-Ish et al: Next generation sequencing-based salivary biomarkers in oral squamous cell carcinoma. J Korean Assoc Oral Maxillofac Surg 2022 
ing is the basis of Roche 454 platform sequencing. The release and incorporation of pyrophosphate into a new strand by polymerase is detected by fluorescence. Multiple reads over 1,000 bp long can be carried out by optical signal detection. One DNA fragment per bead can be annealed, and generic adaptors can add bases to the ends. The product is amplified by PCR as a routine adaptor-specific primers application.

The principle of measuring the direct hydrogen ion release from individual bases, not fluorescence, is the basic principle of Ion torrent and proton platform sequencing. Direct measurement of the emission of hydrogen ions by polymerase during the incorporation of deoxynucleoside triphosphate to a growing DNA strand. This is executed by uniform 200 to 400 bp fragmentation, and adapters are added to effect amplification by emulsion PCR.

\section{Salivary Biomarkers and Oral Cancer}

Saliva sampling is rapidly expanding; and arrays of analytes including proteins, messenger RNA (mRNA), and DNA in saliva have been studied for their potential use as biomarkers for OSCC screening programs ${ }^{32,33}$. OSCC is a malignancy in which salivary diagnosis has the greatest potential because the OSCC environment contains saliva. One of the useful aspects of saliva is its containment of exfoliated tissues or cells from the oral cavity. This aspect suggests the existence of potential salivary biomarkers for $\mathrm{OSCC}^{33}$. A number of candidate salivary biomarkers for oral cancer, including genomic and proteomic biomarkers for OSCC, have been reported and are summarized in Table 2.

Proteomic studies using human saliva have been targeting the biological activities of various peptides and proteins in normal individuals and in those with various pathologies. Proteomic targets such as CD59, catalase, M2BP, and MRP14 were suggested from a shotgun proteome analysis for oral cancer detection ${ }^{34}$. Li et al. ${ }^{35}$ reported the presence of more than 3000 RNA species, mostly mRNAs; and reports of Park et al. ${ }^{36}$ and Patel et al. ${ }^{37}$ support the role of microRNAs (miRNAs) in oral cancer progression and various cancers.

Several salivary biomarkers such as DAPK, TIMP3, p16, and MGMT are potential screening markers for $\mathrm{OSCC}^{38}$, and changes in DNA methylation patterns could be a useful screening tool for predicting the rate and the likelihood of malignant transformation. The methylation of DNA in saliva has been suggested as an effective biomarker for early detection of $\mathrm{OSCC}^{39}$. For example, hypermethylation of the DNA
Table 2. Candidate salivary biomarkers for oral cancer, based on the biomolecule markers ${ }^{1}$

\begin{tabular}{|c|c|}
\hline $\begin{array}{c}\text { Type of } \\
\text { biomolecular } \\
\text { markers }\end{array}$ & Biomarkers \\
\hline \multirow[t]{4}{*}{ Genomic } & $\mathrm{p} 53$ \\
\hline & $\begin{array}{l}\text { Promoter hypermethylation of DAPK, TIMP3, p16, } \\
\text { and MGMT genes }\end{array}$ \\
\hline & Cyclin D1 gene amplification \\
\hline & Maspin \\
\hline \multirow[t]{5}{*}{ mRNA } & IL-8 \\
\hline & IL-1 $\beta$ \\
\hline & S100P \\
\hline & SAT \\
\hline & $\operatorname{miR} 31, \operatorname{miR} 125, \operatorname{miR} 200 \mathrm{a}$ \\
\hline \multirow[t]{9}{*}{ Protein } & Elevated CD44 \\
\hline & IL-6 \\
\hline & Intermediate filament protein (Cyfra 21-1) \\
\hline & 8-OHdG \\
\hline & Albumin \\
\hline & Glutathione \\
\hline & Actin and myosin \\
\hline & L-phenylalanine \\
\hline & EFNB2, ANGPT1, ANGPT2, CD31, VEGF \\
\hline \multirow[t]{2}{*}{ Others } & $\mathrm{HPV}$ and EBV \\
\hline & $\begin{array}{l}\text { Inorganic compounds: } \mathrm{Na}, \mathrm{Ca}, \mathrm{F}, \mathrm{Mg} \\
\text { Fucose }\end{array}$ \\
\hline
\end{tabular}

(DAPK: death-associated protein kinase, TIMP3: tissue inhibitor of metalloproteinase-3, MGMT: O6-methylguanine-DNA methyltransferase, Maspin: mammary serine protease inhibitor, IL-8: interleukin 8, IL$1 \beta$ : interleukin 1 beta, S100P: S100 calcium binding protein P, SAT: spermidine/spermineN1-acetyltransferase, miR: microRNA, CD44: cluster of differentiation 44, 8-OHdG: 8-Oxo-2'-deoxyguanosine, ANGPT: angiopoietin, VEGF: vascular endothelial growth factor, HPV: human papilloma virus, EBV: Epstein-Barr virus)

Buyanbileg Sodnom-Ish et al: Next generation sequencing-based salivary biomarkers in oral squamous cell carcinoma. J Korean Assoc Oral Maxillofac Surg 2022

promoter of certain genes, such as p16, has been found in saliva as well as serum ${ }^{40,41}$. Promoter hypermethylation has been suggested to be an early event during OSCC genesis. Any change of transcription factor or receptor functions or other factors in tumorigenesis might be involved in loss of cell cycle control. This loss of control was reported by Liao et al. ${ }^{42}$; this group suggested the first salivary biomarker, genomic p53. Other cell cycle regulatory proteins such as mammary serine protease inhibitor and cyclin D1 were also increased in OSCC saliva ${ }^{43}$.

Due to the basic precursor characteristics of mRNA for protein expression, other potential salivary biomarkers display increased mRNA production. These include IL-8, IL-1 $\beta$, S100P, and spermidine/spermineN1-acetyltransferase ${ }^{44}$. The circulating levels of CD44 are reported to be related to head and neck cancer metastasis, and CD44 is a potential salivary protein biomarker ${ }^{45}$. Actin and myosin are also regarded as promising salivary biomarkers for premalignant differentiation and malignant oral lesions ${ }^{33}$ IL-6 is another premalignant 
Table 3. NGS-based salivary genomic markers in oral cancer

\begin{tabular}{|c|c|c|}
\hline Potential genomic markers ${ }^{1}$ & Sample/ Collection method & NGS-based studies \\
\hline $\begin{array}{l}\text { p53 (TP53, P53; BCC7; LFS1; } \\
\text { BMFS5; TRP53) }\end{array}$ & $\begin{array}{l}\text { Tumor tissue/ Formalin fixation and paraffin } \\
\text { embedding }\end{array}$ & $\begin{array}{l}\text { Approximately } 30 \% \text { of salivary gland cancers have } \\
\text { mutations of p53 gene. A significant worse overall } \\
\text { and disease-free survival was shown in cancers with } \\
\text { p53 mutations. }\end{array}$ \\
\hline $\begin{array}{l}\text { Promoter hypermethylation of } \\
\text { DAPK gene }{ }^{48,49}\end{array}$ & $\begin{array}{l}\text { UWS/ Oragene DNA Self-Collection kit } \\
\text { Salivary rinse/ 10-20 mL 0.9\% NaCl, } 15-60 \mathrm{~s}\end{array}$ & $\begin{array}{l}\text { DAPK methylation gene was reported with the } \\
\text { development of cancers in women. }\end{array}$ \\
\hline $\begin{array}{l}\text { Promoter hypermethylation of } \\
\text { TIMP3 gene (SFD; K222; } \\
\text { K222TA2; HSMRK222) }\end{array}$ & $\begin{array}{l}\text { Salivary rinse/ rinsing and gargling with } 20 \\
\mathrm{~mL} 0.9 \% \mathrm{NaCl}\end{array}$ & $\begin{array}{l}\text { Promoter hypermethylation of TIMP3 levels found in } \\
\text { the circulating tumor DNA in saliva of disease-free } \\
\text { survival HNSCC patients. }\end{array}$ \\
\hline $\begin{array}{l}\text { Promoter hypermethylation of p16 } \\
\text { (CDKN2A, ARF; MLM; P14; } \\
\text { P19; CMM2; INK4) })^{47,53}\end{array}$ & $\begin{array}{l}\text { Tumor tissue/ Formalin fixation and paraffin } \\
\text { embedding } \\
\text { Salivary rinse/ swishing with } 15 \mathrm{~mL} \text { of } 0.9 \% \\
\text { normal saline, } 15-30 \mathrm{~s}\end{array}$ & $\begin{array}{l}\text { The absolute frequencies of CDKN2A mutations are } \\
\text { detected by NGS. }\end{array}$ \\
\hline $\begin{array}{l}\text { Promoter hypermethylation of } \\
\text { MGMT gene }\end{array}$ & $\begin{array}{l}\text { Tumor tissue/ Formalin fixation and paraffin } \\
\text { embedding } \\
\text { Salivary rinse/ swishing with } 15 \mathrm{~mL} \text { of } 0.9 \% \\
\text { normal saline, } 15-30 \mathrm{~s}\end{array}$ & $\begin{array}{l}\text { MGMT methylation was detected in } 29 \% \text { of oral cancer/ } \\
\text { dysplasia patient, showing MGMT gene is related to } \\
\text { DNA repair and aberrant promoter hypermethylation. }\end{array}$ \\
\hline $\begin{array}{l}\text { Cyclin D1 gene amplification } \\
\text { (CCND1, BCL1; PRAD1; } \\
\text { U21B31; D11S287E) })^{55,56}\end{array}$ & $\begin{array}{l}\text { Tumor tissue/ Formalin fixation and paraffin } \\
\text { embedding }\end{array}$ & $\begin{array}{l}14 \text { of the } 21 \text { genes had copy number amplifications and } \\
\text { losses, which included CCND1 }(83.7 \%) \text {. }\end{array}$ \\
\hline $\operatorname{Maspin}^{57,58}$ & $\begin{array}{l}\text { UWS/ samples were collected in the morning, } \\
\text { without any oral stimulation for } 90 \text { minutes } \\
\text { before collection }\end{array}$ & $\begin{array}{l}\text { Downregulation of maspin; the functional importance of } \\
\text { maspin includes the inhibition of tumor angiogenesis. } \\
\text { The levels of maspin were reduced. }\end{array}$ \\
\hline
\end{tabular}

(NGS: next generation sequencing, DAPK: death-associated protein kinase, UWS: unstimulated whole saliva, TIMP3: tissue inhibitor of metalloproteinase-3, HNSCC: head and neck squamous cell carcinoma, MGMT: O-6-methylguanine-DNA methyltransferase, Maspin: mammary serine protease inhibitor)

Buyanbileg Sodnom-Ish et al: Next generation sequencing-based salivary biomarkers in oral squamous cell carcinoma. J Korean Assoc Oral Maxillofac Surg 2022

differentiation biomarker found especially in the saliva of oral leukoplakia patients. IL-6 inactivated the p53 tumor suppressor gene by hypermethylation of its promoter region resulting in uncontrolled cell proliferation and suppression of programmed cell death ${ }^{33}$.

Researchers have also directed their research toward detection of human papilloma virus (HPV) and Epstein-Barr virus (EBV) in saliva; these viruses are etiological factors in cancer. The incidence for HPV positivity has been reported to be more than $45 \%$ in patients treated for oral cancer ${ }^{33}$.

\section{Current Cancer Biomarkers Using NGS-based Technique}

Currently, several authors have reported data from the search for biomarkers using a NGS-based technique ${ }^{36,46-69}$. (Tables 3, 4) Most of these studies started from Gene Expression Omnibus datasets (https://www.ncbi.nlm.nih.gov/gds) in combination with differentially expressed genes, the proteinprotein interaction network, gene ontology and the Kyoto Encyclopedia of Genes and Genomes pathway. Shanmugam et al. $^{70}$ have reported a customized NGS analysis of unique coding regions of seven mutated genes from OSCC saliva, and similar data from whole-exome sequencing were also discovered in tumors from The Cancer Genome Atlas ${ }^{71}$, the International Cancer Genome Consortium gingiva-buccal cohort $^{69}$, and MD Anderson Cancer Center OSCC cohort ${ }^{72}$.

From this review, NGS-based salivary biomarkers in OSCC could be categorized primarily as genomic (Table 3 ) and transcriptome markers.(Table 4) Within these main categories, we could present promoter hypermethylation of $\mathrm{p} 16$ and three miRNAs as the main candidate salivary biomarkers. Especially, miRNAs, endogenous, non-coding, singlestranded RNA molecules 22 nucleotides long, have tumorcontrolling characteristics including tumor-suppression.

Hypermethylation of the $\mathrm{p} 16$ promoter is a useful serum biomarker for the early detection of alimentary tract cancer, especially gastric cancer. Zammit et al. ${ }^{73}$ reported on the etiology of OSCC using NGS while focusing on smoking and HPV factors in a prospective observational study. This group showed that the most frequent mutations were found in TP53 and CDKN2A in the salivary specimen.(Table 3) Fadhil et $\mathrm{al}^{74}$ reported five miRNAs using NGS data in saliva of 12 HNSCC patients and 12 healthy controls. Among these, miRlet-7a-5p and miR-3928 were suggested to be NGS-based salivary biomarkers for early diagnosis of HNSCC when compared with other miRNAs such as miR-7703, miR-3455p, and miR-1470.(Table 4) A recent study also showed the 
Table 4. NGS-based salivary mRNA markers in oral cancer

\begin{tabular}{|c|c|c|}
\hline Potential mRNA markers ${ }^{1}$ & Sample/ Collection method & NGS-based studies \\
\hline IL-8 (IL8) ${ }^{59,60}$ & $\begin{array}{l}\text { UWS/ samples were collected between } 9 \text { am and } 10 \mathrm{am} \text {, } \\
\text { following the standard protocol. }\end{array}$ & $\begin{array}{l}\text { In oral, esophageal, lung, pancreatic, ovarian } \\
\text { and breast cancers, certain salivary mRNA } \\
\text { biomarkers have been proposed as a possible } \\
\text { cancer biomarker, including IL- } 8 \text {. }\end{array}$ \\
\hline IL-1 $\beta(\mathrm{IL}-1)^{61,62}$ & $\begin{array}{l}\text { UWS/ 3-5 mL salivary specimen was collected into a tube } \\
\text { containing } 10 \mathrm{~mL} \text { of RNAlater (Ambion, Austin, TX, } \\
\text { USA), an aqueous tissue storage reagent that rapidly } \\
\text { permeated tissue to stabilize and protect cellular RNA. } \\
\text { The specimen was then placed on ice at } 4^{\circ} \mathrm{C} \text {; cell-free } \\
\text { saliva supernatant was harvested. }\end{array}$ & $\begin{array}{l}\text { IL- } 1 \beta \text { gene has been found to be an important } \\
\text { biomarker for ovarian cancer. }\end{array}$ \\
\hline $\begin{array}{l}\text { S100P }(\mathrm{S} 100 \text { calcium } \\
\text { binding protein } \mathrm{P})^{63,64}\end{array}$ & $\begin{array}{l}\text { UWS/ samples were collected between } 6 \text { am and } 12 \mathrm{pm} \\
\text { following standard protocol. A maximum of } 8 \mathrm{~mL} \text { of } \\
\text { saliva were collected within } 30 \text { minutes. }\end{array}$ & $\begin{array}{l}\text { Salivary S100 mRNA is a candidate biomarker } \\
\text { for detecting OSCC development and in OLP } \\
\text { patients determined by NGS. }\end{array}$ \\
\hline $\mathrm{SAT}^{69}$ & $\begin{array}{l}\text { UWS/ Participants were asked to refrain from eating, } \\
\text { drinking and any oral hygiene overnight and spit in } \\
\text { 5-mL plastic vials used for biochemical examinations } \\
\text { for } 5 \text { minutes. During the whole procedure and until } \\
\text { centrifugation the vials were kept in ice. }\end{array}$ & $\begin{array}{l}\text { The combination of SAT and IL- } 8 \text { mRNA } \\
\text { biomarkers are attractive candidates either } \\
\text { for screening or for early diagnosis purposes. } \\
\text { These exert a very good prediction ability } \\
\text { together with a high sensitivity and specificity } \\
\text { for screening oral squamous cell carcinoma. }\end{array}$ \\
\hline $\begin{array}{l}\operatorname{miR} 31(\text { MIRN31; miR-31; } \\
\text { hsa-mir-31) }\end{array}$ & $\begin{array}{l}\text { UWS / 3-5 mL saliva was collected from mouth floor } \\
\text { after simple rinsing. Pre-treatment salivary sample } \\
\text { was collected from } 45 \text { patients with OSCC and } 10 \\
\text { patients with oral verrucous leukoplakia and } 24 \text { healthy } \\
\text { participants. }\end{array}$ & $\begin{array}{l}\text { A significantly high expression of miR- } 31 \text { was } \\
\text { found in the saliva sample of patients with } \\
\text { OSCC at all clinical stages by RT-qPCR. More } \\
\text { miR-31 levels were detected in the saliva than } \\
\text { in plasma, suggesting salivary miR-31 to be a } \\
\text { more sensitive. }\end{array}$ \\
\hline $\begin{array}{l}\text { miR } 125 \text { (MIRN125A; mir- } \\
\text { 125a; miRNA125A) }\end{array}$ & $\begin{array}{l}\text { UWS/ an aqueous tissue storage reagent was used to } \\
\text { preserve UWS samples and SUPERase.In (Themo } \\
\text { Fisher Scientific, Waltham, MA, USA) was used for } \\
\text { supernatant saliva preservation. }\end{array}$ & $\begin{array}{l}\text { Significantly lower levels of miR-125a was } \\
\text { found in saliva sample of OSCC patient than } \\
\text { that of healthy controls. }\end{array}$ \\
\hline $\operatorname{miR} 200 a^{36,68}$ & $\begin{array}{l}\text { UWS/ an aqueous tissue storage reagent was used for } \\
\text { the UWS samples and SUPERase.In (Themo Fisher } \\
\text { Scientific) was used for supernatant saliva preservation. }\end{array}$ & $\begin{array}{l}\text { Significantly lower levels of miR 200a was } \\
\text { found in saliva sample of OSCC patient than } \\
\text { that of healthy controls. }\end{array}$ \\
\hline
\end{tabular}

(NGS: next generation sequencing, IL-8: interleukin 8, IL-1ß: interleukin 1 beta, UWS: unstimulated whole saliva, OSCC: oral squamous cell carcinoma, OLP: oral lichen planus, miR: microRNA, RT-qPCR: quantitative real-time reverse transcriptase-polymerase chain reaction)

Standard protocol was summarized as 1) no drinking neither using any oral hygiene care on day of saliva collection, 2) mouth rinsing with water on 5 minutes prior, and 3) upright sitting position and spitting into a 50-mL Falcon tube kept on ice.

Buyanbileg Sodnom-Ish et al: Next generation sequencing-based salivary biomarkers in oral squamous cell carcinoma. J Korean Assoc Oral Maxillofac Surg 2022

Table 5. Known salivary biomarker and recommended NGS-based potential salivary biomarker

\begin{tabular}{llc}
\hline \multicolumn{1}{c}{ Genomic } & Transcriptome (mRNA) \\
\hline Known salivary biomarkers & p53 & miRNA (saliva): miR-let-7a-5p and miR-3928 \\
& FAT1 & Oncogenic (up-regulated, tissue): miR-21, miR-22, miR-26a, \\
& CASP8 & miR34c, miR-34b, miR-117, miR-118, miR-130b, miR-135, \\
& PIK3CA & miR-142, miR-143, miR-148a, miR-150, miR-221, miR-222, \\
& HRAS & miR-423, miR-542, miR-1269a ${ }^{81}$ \\
& NOTCH1 & Suppressive (down-regulated, tissue): miR-92b, miR-199, \\
Recommended NGS-based & CDKN2A ${ }^{80}$ & miR-214, miR-375, miR-486, miR-504, miR-499, miR-486 \\
salivary biomarker & Mutation of p53 gene & miR 31 \\
& Promoter hypermethylation of DAPK, $125^{77}$, miR 200 $^{78,79}$ & \\
& TIMP3, p16, and MGMT genes & \\
& Cyclin D1 gene amplification & \\
& Mammary serine protease inhibitor & \\
\hline
\end{tabular}

(NGS: next generation sequencing, FAT1: AT atypical cadherin 1, CASPS: caspase 8, PIK3CA: phosphatidylinositol-4,5-bisphosphate 3-kinase catalytic subunit alpha, HRAS: Harvey rat sarcoma viral oncogene homolog, NOTCH1: Notch homolog 1, translocation-associated, CDKN2A: cyclindependent kinase inhibitor 2A, DAPK: death-associated protein kinase, TIMP3: tissue inhibitor of metalloproteinase-3, MGMT: O6-methylguanineDNA methyltransferase, miR: microRNA)

Buyanbileg Sodnom-Ish et al: Next generation sequencing-based salivary biomarkers in oral squamous cell carcinoma. J Korean Assoc Oral Maxillofac Surg 2022 
potential benefits of NGS for mRNA expression profiling by using miR143-3p to detect chronic periodontitis ${ }^{75}$.

$\mathrm{Lu}$ et al. ${ }^{76}$ reported that miR-31-5p may be an independent OSCC biomarker by showing its tumor growth inhibition capacity in oral cancer patient-derived xenograft models. Wang et al. ${ }^{77}$ showed that mature miR-125b could control metabolism and immunity of cancer cells by regulating NF- $\mathrm{KB}$ or p53 signaling pathways through translation inhibition of 3 untranslated regions of target mRNAs. Korpal and Kang ${ }^{78}$ also showed that miR-200 family members inhibit epithelialmesenchymal transition (EMT) and metastasis. This occurs through a miRNA-mediated regulatory pathway by direct targeting of transcriptional repressors of E-cadherin, ZEB1, and ZEB2. The validity of this report was strengthened by Kabzinski et al. ${ }^{79}$ who showed that DNA methylation of the miR-200c promoter in an epithelial originated tumor may occur during EMT. Majewska et al. ${ }^{80}$ discovered a potentially targetable novel anaplastic lymphoma kinase fusion in an intraductal carcinoma of a minor salivary gland by NGS analysis.

Compared with known genomic salivary biomarkers, such as p53, FAT1, CASP8, PIK3CA, HRAS, NOTCH1, and CDKN2A, NGS-based genomics consider mutation of $\mathrm{p} 53$ and promoter hypermethylation of DAPK, TIMP3, p16, and MGMT, cyclone D1 and mammary serine protease inhibitors. Also, up-regulated oncogenic tissue miRNAs and downregulated tissue suppressive marker miRNAs, including miR 31, miR 125, and miR 3928, are recommended as subjects for further research ${ }^{70,74,76-79,81}$.(Table 5)

\section{Discussion}

This review article aimed to summarize current applications of NGS in cancer research and to propose potential genomic and proteomic saliva biomarkers for NGS-based study in OSCC screening and diagnosis programs. For the establishment of a standardized research and designed protocol for the detection of trace protein or nucleic acids biomarkers from saliva samples, efficient and stable collection, processing and preservation methods should first be confirmed. For the collection of saliva samples, confirmation of the patient's mouth cleanness is essential. This can be accomplished by rinsing the mouth with water to remove substances and by ensuring that the patient avoids any eating or drinking for at least 30 minutes prior to sampling. Approximately $2.5 \mathrm{~mL}$ of saliva in the buffered solution is recommended. Preparation should include addition of $2.5 \mathrm{~mL}$ of DNA stabilization buffer into a 10- or 15-mL conical tube. Excessive saliva might to be degraded due to insufficient DNA stabilization buffer, and insufficient saliva collection may not provide adequate results. The cap needs to be replaced, mixing needs to occur by inversion not shaking, and the specimen needs to be stored at room temperature for immediate use or at $4{ }^{\circ} \mathrm{C}$ for future use.

NGS-based research has been used to identify factors in metastasis of lung, prostate, ovarian, and bile duct cancer. NGS-based evaluation of candidate biomarkers in saliva could also be routinely used as a simple, non-invasive test in patients with OSCC. NGS has also been used as a valuable tool for detecting novel biomarkers in periodontal disease ${ }^{75}$. More recently, NGS-based research has led the ability to differentiate patients with primary Sjögren's syndrome from those with non-Sjögren's sicca ${ }^{82}$.

In various medical and non-medical institutions, prevention of unnecessary medical expenses may be possible by the quick and easy diagnosis of oral cancer in healthy or suspect patients. There would be no additional cost to the public health system, and provision of information on the potential of benefits to patients with OSCC by using NGS based salivary biomarkers can be effected. Since both proteins and genes can be applied as biomarkers, the accuracy of diagnosis can be increased. New biomarkers can be added quickly for expansion of a preventive platform for a variety of medical and dental diseases. Since both proteins and genes can be applied as biomarkers, the accuracy of diagnosis can be increased, and new biomarkers can be added quickly, so that it can be expanded to a preventive platform through early diagnosis of various diseases as well as various medical and dental treatments.

In conclusion, selection of potential OSCC biomarkers through NGS-based protein studies from epithelial tissue cells in collected saliva will be possible. These non-invasive methods could be a useful tool for the improvement of an immune biosensor for ensuring general public health and for diagnosis of OSCC before its metastasis or progressive infiltration to adjacent tissues. Based on NGS analysis, we will be able to verify the biomarkers of OSCC in saliva and to effect early diagnosis of oral cancer based on this.

\section{ORCID}

Buyanbileg Sodnom-Ish, https://orcid.org/0000-0002-4239-1420

Mi Young Eo, https://orcid.org/0000-0001-7055-9924

Hoon Myoung, $h$ ttps://orcid.org/0000-0002-9984-8479

Jong Ho Lee, https://orcid.org/0000-0002-8843-545X 
Soung Min Kim, https://orcid.org/0000-0002-6916-0489

\section{Authors' Contributions}

B.S.I. and M.Y.E. participated in data collection and wrote the manuscript. H.M. and J.H.L. participated in the study design and helped to draft the manuscript. S.M.K. coordinated and approved the final manuscript.

\section{Acknowledgements}

This study was supported by grant No. 03-2021-0045 from the SNUDH Research Fund.

\section{Conflict of Interest}

No potential conflict of interest relevant to this article was reported.

\section{References}

1. Nguyen TTH, Sodnom-Ish B, Choi SW, Jung HI, Cho J, Hwang I, et al. Salivary biomarkers in oral squamous cell carcinoma. J Korean Assoc Oral Maxillofac Surg 2020;46:301-12. https://doi. org/10.5125/jkaoms.2020.46.5.301

2. Salazar C, Nagadia R, Pandit P, Cooper-White J, Banerjee N, Dimitrova N, et al. A novel saliva-based microRNA biomarker panel to detect head and neck cancers. Cell Oncol (Dordr) 2014;37:331-8. https://doi.org/10.1007/s13402-014-0188-2

3. Pfaffe T, Cooper-White J, Beyerlein P, Kostner K, Punyadeera C. Diagnostic potential of saliva: current state and future applications. Clin Chem 2011;57:675-87. https://doi.org/10.1373/ clinchem.2010.153767

4. Schulz BL, Cooper-White J, Punyadeera CK. Saliva proteome research: current status and future outlook. Crit Rev Biotechnol 2013;33:246-59. https://doi.org/10.3109/07388551.2012.687361

5. Genco RJ. Salivary diagnostic tests. J Am Dent Assoc 2012;143(10 Suppl):3S-5S. https://doi.org/10.14219/jada.archive.2012.0340

6. Fábryová $\mathrm{H}, \mathrm{Celec} \mathrm{P}$. On the origin and diagnostic use of salivary RNA. Oral Dis 2014;20:146-52. https://doi.org/10.1111/odi.12098

7. Campuzano S, Yanez-Sedeno P, Pingarron JM. Electrochemical bioaffinity sensors for salivary biomarkers detection. TrAC Trends Anal Chem 2017;86:14-24. https://doi.org/10.1016/ j.trac.2016.10.002

8. Malon RS, Sadir S, Balakrishnan M, Córcoles EP. Salivabased biosensors: noninvasive monitoring tool for clinical diagnostics. Biomed Res Int 2014;2014:962903. https://doi. org $/ 10.1155 / 2014 / 962903$

9. Maxam AM, Gilbert W. A new method for sequencing DNA. Proc Natl Acad Sci U S A 1977;74:560-4. https://doi.org/10.1073/ pnas.74.2.560

10. Sanger F, Nicklen S, Coulson AR. DNA sequencing with chainterminating inhibitors. Proc Natl Acad Sci U S A 1977;74:5463-7. https://doi.org/10.1073/pnas.74.12.5463

11. Adams J. DNA sequencing technologies. Nat Educ 2008;1:193.

12. Sanger F, Coulson AR. A rapid method for determining sequences in DNA by primed synthesis with DNA polymerase. J Mol Biol 1975;94:441-8. https://doi.org/10.1016/0022-2836(75)90213-2
13. Behjati S, Tarpey PS. What is next generation sequencing? Arch Dis Child Educ Pract Ed 2013;98:236-8. https://doi.org/10.1136/ archdischild-2013-304340

14. Goodwin S, McPherson JD, McCombie WR. Coming of age: ten years of next-generation sequencing technologies. Nat Rev Genet 2016;17:333-51. https://doi.org/10.1038/nrg.2016.49

15. Gabusi A, Gissi DB, Tarsitano A, Asioli S, Marchetti C, Montebugnoli $\mathrm{L}$, et al. Intratumoral heterogeneity in recurrent metastatic squamous cell carcinoma of the oral cavity: new perspectives afforded by multiregion DNA sequencing and mtDNA analysis. J Oral Maxillofac Surg 2019;77:440-55. https://doi.org/10.1016/ j.joms.2018.09.014

16. Todorovic E, Dickson BC, Weinreb I. Salivary gland cancer in the era of routine next-generation sequencing. Head Neck Pathol 2020; 14:311-20. https://doi.org/10.1007/s12105-020-01140-4

17. Massive parallel sequencing [Internet]. San Francisco (CA): Wikipedia [cited 2021 May 30]. Available from: https://en.wikipedia. org/wiki/Massive_parallel_sequencing

18. Harrington CT, Lin EI, Olson MT, Eshleman JR. Fundamentals of pyrosequencing. Arch Pathol Lab Med 2013;137:1296-303. https:// doi.org/10.5858/arpa.2012-0463-RA

19. The Next Generation Sequencing Platform of Roche 454 [Internet]. Shirley (NY): Biogene Blog [cited 2021 May 30]. Available from: https://www.creative-biogene.com/blog/index. php/2017/02/02/the-next-generation-sequencing-platformof-roche-454/\#: :text=Roche $\% 20454 \% 20$ sequencing $\% 20$ system $\% 20$ is, the $\% 20$ next $\% 20$ generation $\% 20$ sequencing $\% 20$ technology.\&text=DNA $\% 20$ Library $\% 20$ construction $\% 20 \mathrm{in} \% 20$ 454,different $\% 20$ adapters $\% 20$ at $\% 20$ both $\% 20$ ends

20. Gilles A, Meglécz E, Pech N, Ferreira S, Malausa T, Martin JF. Accuracy and quality assessment of 454 GS-FLX Titanium pyrosequencing. BMC Genomics 2011;12:245. https://doi. org/10.1186/1471-2164-12-245

21. 454 Life sciences [Internet]. San Francisco (CA): Wikipedia [cited 2021 May 30]. Available from: https://en.wikipedia.org/wiki/454 Life Sciences

22. Ravi RK, Walton K, Khosroheidari M. MiSeq: a next generation sequencing platform for genomic analysis. Methods Mol Biol 2018;1706:223-32. https://doi.org/10.1007/978-1-4939-7471-9_12

23. Illumina. HiSeq ${ }^{\mathrm{TM}}$ sequencing systems: redefining the trajectory of sequencing [Internet]. San Diego (CA): Illumina [cited 2021 May 30]. Available from: https://www.illumina.com/documents/products/datasheets/datasheet hiseq_systems.pdf

24. Illumina. Genome Analyzer ${ }_{\text {IIx }}$ system: the most proven, widely adopted next-generation sequencing platform [Internet]. San Diego (CA): Illumina [cited 2021 May 30]. Available from: https://support.illumina.com/content/dam/illumina-marketing/documents/ products/datasheets/datasheet_genome_analyzeriix.pdf

25. Castellana S, Romani M, Valente EM, Mazza T. A solid qualitycontrol analysis of AB SOLiD short-read sequencing data. Brief Bioinform 2013;14:684-95. https://doi.org/10.1093/bib/bbs048

26. ABI Solid Sequencing [Internet]. San Francisco (CA): Wikipedia [cited 2021 May 30]. Available from: https://en.wikipedia.org/wiki/ ABI_Solid_Sequencing

27. Thermo Fisher Scientific. Ion Proton ${ }^{\mathrm{TM}}$ System for next-generation sequencing [Internet]. Seoul: Thermo Fisher Scientific [cited 2021 May 30]. Available from: https://www.thermofisher.com $/ \mathrm{kr} / \mathrm{ko} /$ home/life-science/sequencing/next-generation-sequencing/iontorrent-next-generation-sequencing-workflow/ion-torrent-nextgeneration-sequencing-run-sequence/ion-proton-system-for-nextgeneration-sequencing.html

28. Complete genomics [Internet]. San Francisco (CA): Wikipedia [cited 2021 May 30]. Available from: https://en.wikipedia.org/wiki/ Complete_Genomics

29. Thompson JF, Steinmann KE. Single molecule sequencing with a HeliScope genetic analysis system. Curr Protoc Mol Biol 2010;Chapter 7:Unit7.10. https://doi.org/10.1002/0471142727.mb0710s92 
30. Helicos single molecule fluorescent sequencing [Internet]. San Francisco (CA): Wikipedia [cited 2021 May 30]. Available from: https://en.wikipedia.org/wiki/Helicos_single_molecule_fluorescent_sequencing

31. PacBio. SMRT sequencing [Internet]. Menlo Park (CA): PacBio [cited 2021 May 30]. Available from: https://www.pacb.com/smrtscience/smrt-sequencing/

32. Wong DT. Salivaomics. J Am Dent Assoc 2012;143(10 Suppl):19S24S. https://doi.org/10.14219/jada.archive.2012.0339

33. Shah FD, Begum R, Vajaria BN, Patel KR, Patel JB, Shukla SN, et al. A review on salivary genomics and proteomics biomarkers in oral cancer. Indian J Clin Biochem 2011;26:326-34. https://doi. org/10.1007/s12291-011-0149-8

34. Singh P, Verma JK, Singh JK. Validation of salivary markers, IL$1 \beta$, IL-8 and Lgals3bp for detection of oral squamous cell carcinoma in an Indian population. Sci Rep 2020;10:7365. https://doi. org/10.1038/s41598-020-64494-3

35. Li Y, Zhou X, St John MA, Wong DT. RNA profiling of cell-free saliva using microarray technology. J Dent Res 2004;83:199-203. https://doi.org/10.1177/154405910408300303

36. Park NJ, Zhou H, Elashoff D, Henson BS, Kastratovic DA, Abemayor E, et al. Salivary microRNA: discovery, characterization, and clinical utility for oral cancer detection. Clin Cancer Res 2009; 15:5473-7. https://doi.org/10.1158/1078-0432.CCR-09-0736

37. Patel RS, Jakymiw A, Yao B, Pauley BA, Carcamo WC, Katz J, et al. High resolution of microRNA signatures in human whole saliva. Arch Oral Biol 2011;56:1506-13. https://doi.org/10.1016/ j.archoralbio.2011.05.015

38. Rapado-González Ó, López-Cedrún JL, López-López R, Rodríguez-Ces AM, Suárez-Cunqueiro MM. Saliva gene promoter hypermethylation as a biomarker in oral cancer. J Clin Med 2021;10: 1931. https://doi.org/10.3390/jcm10091931

39. Viet CT, Schmidt BL. Methylation array analysis of preoperative and postoperative saliva DNA in oral cancer patients. Cancer Epidemiol Biomarkers Prev 2008;17:3603-11. https://doi. org/10.1158/1055-9965.EPI-08-0507

40. Nakahara Y, Shintani S, Mihara M, Hino S, Hamakawa H. Detection of p16 promoter methylation in the serum of oral cancer patients. Int J Oral Maxillofac Surg 2006;35:362-5. https://doi. org/10.1016/j.ijom.2005.08.005

41. Viet CT, Jordan RC, Schmidt BL. DNA promoter hypermethylation in saliva for the early diagnosis of oral cancer. J Calif Dent Assoc 2007:35:844-9.

42. Liao PH, Chang YC, Huang MF, Tai KW, Chou MY. Mutation of p53 gene codon 63 in saliva as a molecular marker for oral squamous cell carcinomas. Oral Oncol 2000;36:272-6. https://doi. org/10.1016/s1368-8375(00)00005-1

43. Shpitzer T, Hamzany Y, Bahar G, Feinmesser R, Savulescu D, Borovoi I, et al. Salivary analysis of oral cancer biomarkers. Br J Cancer 2009;101:1194-8. https://doi.org/10.1038/sj.bjc.6605290

44. Zimmermann BG, Wong DT. Salivary mRNA targets for cancer diagnostics. Oral Oncol 2008;44:425-9. https://doi.org/10.1016/ j.oraloncology.2007.09.009

45. Franzmann EJ, Reategui EP, Carraway KL, Hamilton KL, Weed DT, Goodwin WJ. Salivary soluble CD44: a potential molecular marker for head and neck cancer. Cancer Epidemiol Biomarkers Prev 2005;14:735-9. https://doi.org/10.1158/1055-9965.EPI-040546

46. TP53 tumor protein p53 [Homo sapiens (human)] [Internet]. Bethesda (MD): National Center for Biotechnology Information [cited $2021 \mathrm{Feb} 21$ ]. Available from: https://www.ncbi.nlm.nih.gov/ gene/7157

47. Grünewald I, Vollbrecht C, Meinrath J, Meyer MF, Heukamp LC, Drebber U, et al. Targeted next generation sequencing of parotid gland cancer uncovers genetic heterogeneity. Oncotarget 2015;6: 18224-37. https://doi.org/10.18632/oncotarget.4015

48. DAPK1 death associated protein kinase 1 [Homo sapiens (human)]
[Internet]. Bethesda (MD): National Center for Biotechnology Information [cited $2021 \mathrm{Feb} 21]$. Available from: https://www.ncbi nlm.nih.gov/gene/1612

49. Rettori MM, de Carvalho AC, Bomfim Longo AL, de Oliveira CZ, Kowalski LP, Carvalho AL, et al. Prognostic significance of TIMP3 hypermethylation in post-treatment salivary rinse from head and neck squamous cell carcinoma patients. Carcinogenesis 2013;34: 20-7. https://doi.org/10.1093/carcin/bgs311

50. TIMP3 TIMP metallopeptidase inhibitor 3 [Homo sapiens (human)] [Internet]. Bethesda (MD): National Center for Biotechnology Information [cited $2021 \mathrm{Feb} 21]$. Available from: https://www.ncbi. nlm.nih.gov/gene/7078

51. Sun W, Zaboli D, Wang H, Liu Y, Arnaoutakis D, Khan T, et al Detection of TIMP3 promoter hypermethylation in salivary rinse as an independent predictor of local recurrence-free survival in head and neck cancer. Clin Cancer Res 2012;18:1082-91. https://doi. org/10.1158/1078-0432.CCR-11-2392

52. Cristaldi M, Mauceri R, Di Fede O, Giuliana G, Campisi G, Panzarella V. Salivary biomarkers for oral squamous cell carcinoma diagnosis and follow-up: current status and perspectives. Front Physiol 2019;10:1476. https://doi.org/10.3389/fphys.2019.01476

53. CDKN2A cyclin dependent kinase inhibitor 2A [Homo sapiens (human)] [Internet]. Bethesda (MD): National Center for Biotechnology Information [cited $2021 \mathrm{Feb} 21$ ]. Available from: https:// www.ncbi.nlm.nih.gov/gene/1029

54. MGMT O-6-methylguanine-DNA methyltransferase [Homo sapiens (human)] [Internet]. Bethesda (MD): National Center for Biotechnology Information [cited 2021 Feb 21]. Available from: https://www.ncbi.nlm.nih.gov/gene/4255

55. CCND1 cyclin D1 [Homo sapiens (human)] [Internet]. Bethesda (MD): National Center for Biotechnology Information [cited 2021 Feb 21]. Available from: https://www.ncbi.nlm.nih.gov/gene/595

56. Ku BM, Jung HA, Sun JM, Ko YH, Jeong HS, Son YI, et al. Highthroughput profiling identifies clinically actionable mutations in salivary duct carcinoma. J Transl Med 2014;12:299. https://doi. org/10.1186/s12967-014-0299-6

57. SERPINB5 serpin family B member 5 [Homo sapiens (human)] [Internet]. Bethesda (MD): National Center for Biotechnology Information [cited $2021 \mathrm{Feb} 21]$. Available from: https://www.ncbi. nlm.nih.gov/gene/5268

58. Chattopadhyay I, Panda M. Recent trends of saliva omics biomarkers for the diagnosis and treatment of oral cancer. J Oral Biosci 2019;61:84-94. https://doi.org/10.1016/j.job.2019.03.002

59. CXCL8 C-X-C motif chemokine ligand 8 [Homo sapiens (human)] [Internet]. Bethesda (MD): National Center for Biotechnology Information [cited $2021 \mathrm{Feb} 21]$. Available from: https://www.ncbi. nlm.nih.gov/gene/3576

60. Cheng J, Nonaka T, Wong DTW. Salivary exosomes as nanocarriers for cancer biomarker delivery. Materials (Basel) 2019;12:654. https://doi.org/10.3390/ma12040654

61. L1B interleukin 1 beta [Homo sapiens (human)] [Internet]. Bethesda (MD): National Center for Biotechnology Information [cited 2021 Feb 21]. Available from: https://www.ncbi.nlm.nih.gov/gene/3553

62. Lee YH, Kim JH, Zhou H, Kim BW, Wong DT. Salivary transcriptomic biomarkers for detection of ovarian cancer: for serous papillary adenocarcinoma. J Mol Med (Berl) 2012;90:427-34. https:// doi.org/10.1007/s00109-011-0829-0

63. S100P S100 calcium binding protein P [Homo sapiens (human)] [Internet]. Bethesda (MD): National Center for Biotechnology Information [cited $2021 \mathrm{Feb} 21]$. Available from: https://www.ncbi. nlm.nih.gov/gene/6286

64. Cheng YS, Jordan L, Rees T, Chen HS, Oxford L, Brinkmann O, et al. Levels of potential oral cancer salivary mRNA biomarkers in oral cancer patients in remission and oral lichen planus patients. Clin Oral Investig 2014;18:985-93. https://doi.org/10.1007/s00784013-1041-0 Erratum in: Clin Oral Investig 2014;18:995. https:// doi.org/10.1007/s00784-013-1127-8 
65. MIR31 microRNA 31 [Homo sapiens (human)] [Internet]. Bethesda (MD): National Center for Biotechnology Information [cited 2021 Feb 21]. Available from: https://www.ncbi.nlm.nih.gov/ gene $/ 407035$

66. Liu CJ, Lin SC, Yang CC, Cheng HW, Chang KW. Exploiting salivary miR-31 as a clinical biomarker of oral squamous cell carcinoma. Head Neck 2012;34:219-24. https://doi.org/10.1002/hed.21713

67. MIR125A microRNA 125a [Homo sapiens (human)] [Internet]. Bethesda (MD): National Center for Biotechnology Information [cited 2021 Feb 21]. Available from: https://www.ncbi.nlm.nih.gov/ gene $/ 406910$

68. MIR200A microRNA 200a [Homo sapiens (human)] [Internet]. Bethesda (MD): National Center for Biotechnology Information [cited $2021 \mathrm{Feb} 21$ ]. Available from: https://www.ncbi.nlm.nih.gov/ gene $/ 406983$

69. India Project Team of the International Cancer Genome Consortium. Mutational landscape of gingivo-buccal oral squamous cell carcinoma reveals new recurrently-mutated genes and molecular subgroups. Nat Commun 2013;4:2873. https://doi.org/10.1038/ ncomms 3873

70. Shanmugam A, Hariharan AK, Hasina R, Nair JR, Katragadda S, Irusappan S, et al. Ultrasensitive detection of tumor-specific mutations in saliva of patients with oral cavity squamous cell carcinoma. Cancer 2021;127:1576-89. https://doi.org/10.1002/cncr.33393

71. Hoadley KA, Yau C, Hinoue T, Wolf DM, Lazar AJ, Drill E, et al. Cell-of-origin patterns dominate the molecular classification of 10,000 tumors from 33 types of cancer. Cell 2018;173:291-304.e6. https://doi.org/10.1016/j.cell.2018.03.022

72. Pickering CR, Zhang J, Yoo SY, Bengtsson L, Moorthy S, Neskey $\mathrm{DM}$, et al. Integrative genomic characterization of oral squamous cell carcinoma identifies frequent somatic drivers. Cancer Discov 2013;3:770-81. https://doi.org/10.1158/2159-8290.CD-12-0537

73. Zammit AP, Sinha R, Cooper CL, Perry CFL, Frazer IH, Tuong $\mathrm{ZK}$. Examining the contribution of smoking and HPV towards the etiology of oral cavity squamous cell carcinoma using highthroughput sequencing: a prospective observational study. PLoS One 2018;13:e0205406. https://doi.org/10.1371/journal. pone. 0205406

74. Fadhil RS, Wei MQ, Nikolarakos D, Good D, Nair RG. Salivary microRNA miR-let-7a-5p and miR-3928 could be used as potential diagnostic bio-markers for head and neck squamous cell carcino- ma. PLoS One 2020;15:e0221779. https://doi.org/10.1371/journal. pone. 0221779

75. Nisha KJ, Janam P, Harshakumar K. Identification of a novel salivary biomarker miR-143-3p for periodontal diagnosis: a proof of concept study. J Periodontol 2019;90:1149-59. https://doi. org/10.1002/JPER.18-0729

76. $\mathrm{Lu} \mathrm{Z,} \mathrm{He} \mathrm{Q,} \mathrm{Liang} \mathrm{J,} \mathrm{Li} \mathrm{W,} \mathrm{Su} \mathrm{Q,} \mathrm{Chen} \mathrm{Z,} \mathrm{et} \mathrm{al.} \mathrm{miR-31-5p} \mathrm{is} \mathrm{a} \mathrm{po-}$ tential circulating biomarker and therapeutic target for oral cancer. Mol Ther Nucleic Acids 2019;16:471-80. https://doi.org/10.1016/ j.omtn.2019.03.012

77. Wang Y, Zeng G, Jiang Y. The emerging roles of miR-125b in cancers. Cancer Manag Res 2020;12:1079-88. https://doi.org/10.2147/ CMAR.S232388

78. Korpal M, Kang Y. The emerging role of miR-200 family of microRNAs in epithelial-mesenchymal transition and cancer metastasis. RNA Biol 2008;5:115-9. https://doi.org/10.4161/rna.5.3.6558

79. Kabzinski J, Maczynska M, Majsterek I. MicroRNA as a novel biomarker in the diagnosis of head and neck cancer. Biomolecules 2021;11:844. https://doi.org/10.3390/biom11060844

80. Majewska H, Gorczyński A, Czapiewski P, Menon R, Mueller J, Lakis $\mathrm{S}$, et al. ALK alterations in salivary gland carcinomas. Virchows Arch 2021;478:933-41. https://doi.org/10.1007/s00428-02002971-w

81. Kim S, Lee JW, Park YS. The application of next-generation sequencing to define factors related to oral cancer and discover novel biomarkers. Life (Basel) 2020;10:228. https://doi.org/10.3390/ life 10100228

82. Sembler-Møller ML, Belstrøm D, Locht H, Enevold C, Pedersen AML. Next-generation sequencing of whole saliva from patients with primary Sjögren's syndrome and non-Sjögren's sicca reveals comparable salivary microbiota. J Oral Microbiol 2019;11: 1660566. https://doi.org/10.1080/20002297.2019.1660566

How to cite this article: Sodnom-Ish B, Eo MY, Myoung H, Lee JH, Kim SM. Next generation sequencing-based salivary biomarkers in oral squamous cell carcinoma. J Korean Assoc Oral Maxillofac Surg 2022;48:3-12. https://doi.org/10.5125/jkaoms.2022.48.1.3 